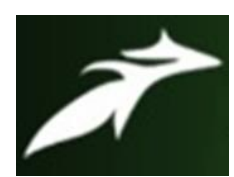

MOHAN RAJ C et al, International Journal of Advances in Agricultural Science and Technology,

Vol.8 Issue.2, February-2021, pg. 55-61

ISSN: 2348-1358

Impact Factor: 6.057

NAAS Rating: 3.77

\title{
Tomato Seeds Bioprimed with Bioagents to Control Seed-Borne Pathogens
}

\author{
MOHAN RAJ C ${ }^{1}$; S. SUNDARESWARAN ${ }^{2}$ \\ ${ }^{1} \mathrm{Ph} . \mathrm{D}$ Scholar, Department of Seed Science and Technology \\ ${ }^{2}$ Professor, Department of Seed Science and Technology \\ Tamil Nadu Agricultural University, Coimbatore - 641003 \\ Email: mohan.rj3@gmail.com \\ DOI: 10.47856/ijaast.2021.v08i2.008
}

\begin{abstract}
Laboratory experiment was carried out to study the effect of biopriming with bioagents on the control of seed borne pathogens in tomato. Tomato seeds cv. PKM 1 were bioprimed with different bio-agents viz., Bacillus subtilis 1 at $6 \%$ concentration for 9 hours, Methylobacterium extorquens AM 1 at 4\% concentration for 9 hours, Pseudomonas fluorescens $\mathrm{Pf} 1$ at $8 \%$ concentration for 9 hours and hydropriming with water for 9 hours along with nonprimed seeds. Sterilized seeds bioprimed with Pseudomonas fluorescens Pf lat $8 \%$ concentration for 9 hours expressed less pathogen infection of Aspergillus flavus $(0.2 \%)$, Aspergillus niger (0.2\%), Fusarium sp. (2.5\%) and Non- sporulating fungi $(0.2 \%)$ than nonprimed seeds when tested in blotter paper method. In agar plate method also, the infection of Aspergillus flavus (0.2\%), Aspergillus niger (0.4\%), Fusarium.sp (0.2\%) and Nonsporulating fungi $(2.5 \%)$ were significantly minimum in sterilized seeds treated with Pseudomonas fluorescens Pf 1 at $8 \%$ concentration for 9 hours when compared to nonprimed seeds.
\end{abstract}

KEYWORDS: Tomato, bioprimed, bio-agents, seed borne, pathogen.

\section{INTRODUCTION}

Tomato (Solanum lycopersicum) is one of the important vegetable in the world which belongs to Solanaceae family. Tomato is a sprawling herbaceous plant with weak woody stem. Tomato is considered as protective foods because of its special nutritive value. Seed priming is a pre-sowing seed treatment where seed hydration is done used to improve crop performance. Priming is a process for improving germination and uniformity of heterogeneously matured seed lots (Olouch and Welbaum, 1996). Seed priming can improve germination and emergence seeds of vegetables and small seeded grasses (Bradford, 1986). 


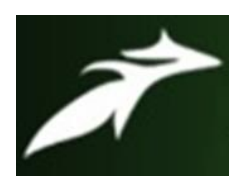

MOHAN RAJ C et al, International Journal of Advances in Agricultural Science and Technology, Vol.8 Issue.2, February-2021, pg. 55-61

ISSN: 2348-1358

Impact Factor: 6.057

\section{MATERIALS AND METHODS}

NAAS Rating: 3.77

Genetically pure seeds of tomato cv. PKM 1 obtained from obtained from the Horticultural College and Research Institute, Periyakulam ,Tamil Nadu were bioprimed with bio-agents viz., Bacillus subtilis 1, Methylobacterium extorquens AM 1 and Pseudomonas fluorescens Pf 1 obtained from the Department of Agricultural Microbiology and Department of Plant pathology, Tamil Nadu Agricultural University, Coimbatore. The laboratory experiment was conducted to standardize suitable biopriming treatments to improve seed health in completely randomized design (CRD) at the Department of Seed Science and Technology, Tamil Nadu Agricultural University, Coimbatore. For priming treatments, unsterilized (US) and sterilized (S) seeds which were soaked in $0.1 \%$ mercuric chloride solution for 1 to $2 \mathrm{~min}$ then washed by sterilized distilled water were used.

The data were analysed for the ' $\mathrm{F}$ ' test of significance as per the methods described by Panse and Sukhatme (1985).

\section{Treatment details}

S- Sterilized seed; US- Unsterilized seed

$\mathrm{T}_{0}$ - Nonprimed seeds

$\mathrm{T}_{1}$ - Hydropriming for 9 hours

$\mathrm{T}_{2}$-Biopriming with Bacillus subtilis 1at $6 \%$ concentration for 9 hours

$\mathrm{T}_{3}$ - Biopriming with Methylobacterium extorquens $A M 1$ at $4 \%$ concentration for 9 hours $\mathrm{T}_{4}$ - Biopriming with Pseudomonas fluorescens Pf 1 at $8 \%$ concentration for 9 hours

\section{Blotter paper method:}

This method was proper used for the detection of seed borne mycoflora as suggested by ISTA (2010). One hundred seeds from each treatment in four replicates were plated equidistantly in Petri dishes of $9 \mathrm{~cm}$ diameter on three layered well soaked filter paper under sterilized condition and were incubated at $20 \pm 2{ }^{\circ} \mathrm{C}$ under $12 \mathrm{~h}$ of alternate cycles of near ultraviolet light (NUV) and darkness for seven days. On 8th day, the seeds were examined for presence of fungi under stereo-binocular microscope, and further confirmation was made 


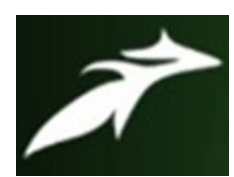

MOHAN RAJ C et al, International Journal of Advances in Agricultural Science and Technology, Vol.8 Issue.2, February-2021, pg. 55-61

ISSN: 2348-1358

Impact Factor: 6.057

NAAS Rating: 3.77

under compound microscope. The number of infected seeds were counted and expressed in percentage. Besides, the kind of fungi present were also identified and documented.

Pathogen infection $(\%)=$ Number of seed infected $/$ Total number of seeds $* 100$

\section{Agar plate method}

In this method, one hundred seeds from each treatment in four replicates were plated on an agar medium and the plated seeds were usually incubated for 7 days at $25{ }^{\circ} \mathrm{C}$ under 12th alternating cycles of light and darkness. At the end of the incubation period, fungi growing out from seeds on the medium were examined and identified. Identification is done based on the colony characters and morphology of sporulating structures under a compound microscope.

Pathogen infection $(\%)=$ Number of seed infected $/$ Total number of seeds $* 100$

\section{RESULTS AND DISCUSSION}

\section{Pathogen infection percentage in blotter paper method}

Among the treatments, $\mathrm{T}_{4}(\mathrm{~S})$ recorded the minimum pathogen infection of Aspergillus flavus (0.2\%), Aspergillus niger (0.2\%), Fusarium.sp (2.5\%) and Non sporulating fungi (0.2\%); whereas the maximum pathogen infection of Aspergillus flavus (2.7\%), Aspergillus niger (9.6\%), Fusarium.sp (9.0\%) and Non sporulating fungi (4.4\%) was recorded in $\mathrm{T}_{0}$ followed by $\mathrm{T}_{1}$ (US) which recorded the infection of Aspergillus flavus (2.7\%), Aspergillus niger (8.2\%), Fusarium .sp (9.0\%) and Non sporulating fungi (3.7\%). (Table 1, Fig. 2)

Table 1. Effect of seed biopriming on pathogen infection on the seeds of tomato cv. PKM 1 by blotter paper method.

\begin{tabular}{|l|l|l|l|l|}
\hline \multirow{2}{*}{ Treatments } & \multicolumn{4}{|c|}{ Pathogen infection (\%) } \\
\cline { 2 - 5 } & $\begin{array}{l}\text { Aspergillus } \\
\text { flavus }\end{array}$ & $\begin{array}{l}\text { Aspergillus } \\
\text { niger }\end{array}$ & $\begin{array}{l}\text { Fusarium } \\
\text { sp }\end{array}$ & $\begin{array}{l}\text { Non sporulating } \\
\text { fungi }\end{array}$ \\
\hline $\mathrm{T}_{0}$ & $2.7(9.46)$ & $9.6(18.05)$ & $9.0(17.66)$ & $4.4(12.11)$ \\
\hline $\mathrm{T}_{1}(\mathrm{US})$ & $2.7(9.46)$ & $8.2(16.64)$ & $9.0(17.66)$ & $3.7(11.09)$ \\
\hline $\mathrm{T}_{1}(\mathrm{~S})$ & $2.2(8.53)$ & $8.2(16.64)$ & $7.0(15.56)$ & $3.2(10.30)$ \\
\hline $\mathrm{T}_{2}(\mathrm{US})$ & $1.2(6.29)$ & $3.7(11.09)$ & $4.5(12.52)$ & $2.2(08.53)$ \\
\hline
\end{tabular}




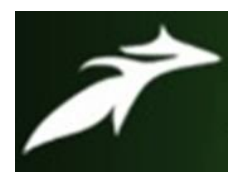

MOHAN RAJ C et al, International Journal of Advances in Agricultural Science and Technology, Vol.8 Issue.2, February-2021, pg. 55-61

ISSN: 2348-1358

Impact Factor: 6.057

NAAS Rating: 3.77

\begin{tabular}{|l|l|l|l|l|}
\hline $\mathrm{T}_{2}(\mathrm{~S})$ & $1.2(6.29)$ & $4.0(11.54)$ & $3.2(10.63)$ & $2.2(08.53)$ \\
\hline $\mathrm{T}_{3}(\mathrm{US})$ & $1.7(7.49)$ & $4.7(12.52)$ & $5.0(13.18)$ & $3.4(10.63)$ \\
\hline $\mathrm{T}_{3}(\mathrm{~S})$ & $1.2(6.29)$ & $4.2(11.83)$ & $4.0(11.83)$ & $3.2(10.30)$ \\
\hline $\mathrm{T}_{4}(\mathrm{US})$ & $0.2(2.56)$ & $1.4(06.80)$ & $3.4(10.94)$ & $0.2(02.56)$ \\
\hline $\mathrm{T}_{4}(\mathrm{~S})$ & $0.2(2.56)$ & $0.2(02.56)$ & $2.5(09.46)$ & $0.2(02.56)$ \\
\hline Mean & $\mathbf{1 . 4 ( 6 . 8 0 )}$ & $\mathbf{4 . 9}(\mathbf{1 2 . 7 9})$ & $\mathbf{5 . 2 ( 1 3 . 4 4 )}$ & $\mathbf{2 . 5 ( 0 9 . 1 0 )}$ \\
\hline SEd & 0.05 & 0.10 & 0.06 & 0.06 \\
\hline $\begin{array}{l}\text { CD } \\
(\mathbf{P = 0 . 0 5})\end{array}$ & 0.10 & 0.21 & 0.14 & 0.13 \\
\hline
\end{tabular}

* Values in parentheses are arcsine transformed values

\section{Treatment details}

S- Sterilized seed; US- Unsterilized seed

$\mathrm{T}_{0}$ - Nonprimed seeds

$\mathrm{T}_{1}$ - Hydropriming for 9 hours

$\mathrm{T}_{2}$-Biopriming with Bacillus subtilis 1at $6 \%$ concentration for 9 hours

$\mathrm{T}_{3}$ - Biopriming with Methylobacterium extorquens AM 1 at $4 \%$ concentration for 9 hours

$\mathrm{T}_{4}$ - Biopriming with Pseudomonas fluorescens Pf 1 at $8 \%$ concentration for 9 hours

Fig.1. Effect of seed biopriming on pathogen infection on the seeds of tomato cv.

\section{PKM 1 (Blotter paper method).}

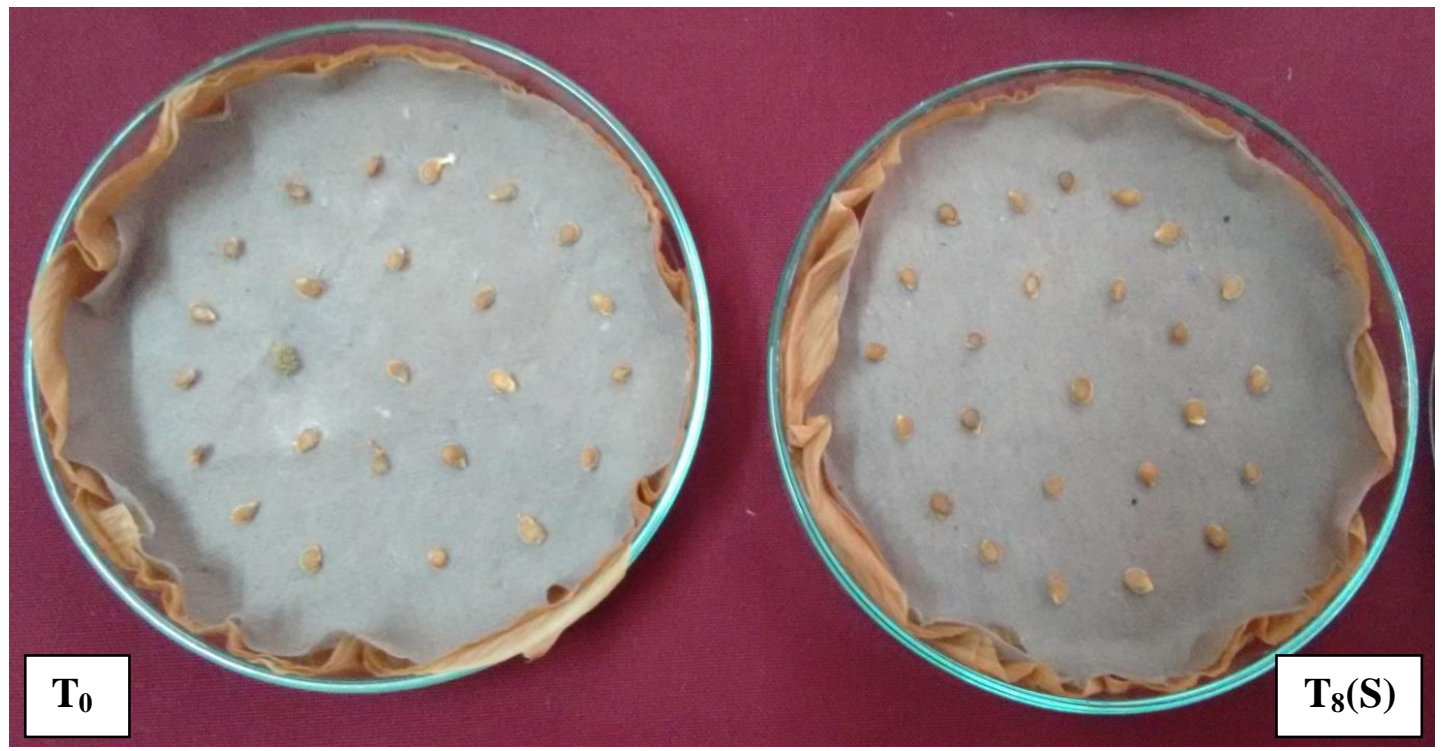

S- Sterilized seed; US- Unsterilized seed

$T_{0}$ - Nonprimed control

$\mathrm{T}_{4}$ (S) - Biopriming with Pseudomonas fluorescens Pf 1 at $8 \%$ concentration for 9 hours 


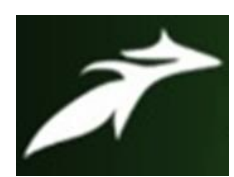

MOHAN RAJ C et al, International Journal of Advances in Agricultural Science and Technology, Vol.8 Issue.2, February-2021, pg. 55-61

ISSN: 2348-1358

Impact Factor: 6.057

NAAS Rating: 3.77

\section{Pathogen infection percentage in agar plate method}

Significant differences were observed among the priming agent for pathogen infection under agar plate method also. Among the treatments, $\mathrm{T}_{4}(\mathrm{~S})$ recorded the minimum pathogen infection of Aspergillus flavus (0.2\%), Aspergillus niger (0.4\%), Fusarium.sp (0.2\%) and Non sporulating fungi (2.5\%); whereas the maximum pathogen infection of Aspergillus flavus (2.8\%), Aspergillus niger (8.3\%), Fusarium.sp (3.8\%) and Non sporulating fungi (8.0\%) was recorded in $\mathrm{T}_{0}$ followed by $\mathrm{T}_{1}(\mathrm{US})$ which showed the infection of Aspergillus flavus (2.5\%), Aspergillus niger (7.5\%), Fusarium .sp (3.5\%) and Non sporulating fungi $(8.4 \%)$.

Table 2. Effect of seed biopriming on pathogen infection on the seeds of tomato $\mathrm{cv}$. PKM 1 by agar plate method.

\begin{tabular}{|l|l|l|l|l|}
\hline \multirow{2}{*}{ Treatments } & \multicolumn{4}{|c|}{ Pathogen infection (\%) } \\
\cline { 2 - 5 } & $\begin{array}{l}\text { Aspergillus } \\
\text { flavus }\end{array}$ & $\begin{array}{l}\text { Aspergillus } \\
\text { niger }\end{array}$ & $\begin{array}{l}\text { Fusarium } \\
\text { sp }\end{array}$ & $\begin{array}{l}\text { Non sporulating } \\
\text { fungi }\end{array}$ \\
\hline $\mathrm{T}_{0}$ & $2.8(9.63)$ & $8.3(16.74)$ & $3.8(11.24)$ & $8.0(16.43)$ \\
\hline $\mathrm{T}_{1}(\mathrm{US})$ & $2.5(9.10)$ & $7.5(15.89)$ & $3.5(10.78)$ & $8.4(16.85)$ \\
\hline $\mathrm{T}_{1}(\mathrm{~S})$ & $2.5(9.10)$ & $7.3(15.68)$ & $3.4(10.63)$ & $6.9(15.23)$ \\
\hline $\mathrm{T}_{2}(\mathrm{US})$ & $1.7(7.49)$ & $4.0(11.54)$ & $2.1(08.33)$ & $5.1(13.05)$ \\
\hline $\mathrm{T}_{2}(\mathrm{~S})$ & $2.2(8.53)$ & $2.8(09.63)$ & $2.0(08.13)$ & $3.6(10.94)$ \\
\hline $\mathrm{T}_{3}(\mathrm{US})$ & $1.5(7.03)$ & $3.9(11.39)$ & $3.8(11.24)$ & $4.2(11.83)$ \\
\hline $\mathrm{T}_{3}(\mathrm{~S})$ & $1.5(7.03)$ & $3.5(10.78)$ & $3.0(09.97)$ & $3.7(11.09)$ \\
\hline $\mathrm{T}_{4}(\mathrm{US})$ & $1.2(6.29)$ & $0.6(04.44)$ & $0.2(02.56)$ & $2.4(08.91)$ \\
\hline $\mathrm{T}_{4}(\mathrm{~S})$ & $0.2(2.56)$ & $0.4(03.63)$ & $0.2(02.56)$ & $2.5(09.10)$ \\
\hline Mean & $\mathbf{1 . 7}(\mathbf{7 . 4 9})$ & $\mathbf{4 . 2 ( 1 1 . 8 3 )}$ & $\mathbf{2 . 4}(\mathbf{0 8 . 9 1})$ & $\mathbf{4 . 9 ( 1 2 . 7 9 )}$ \\
\hline SEd & 0.04 & 0.08 & 0.05 & 0.08 \\
\hline CD (P=0.05) & 0.10 & 0.17 & 0.10 & 0.16 \\
\hline
\end{tabular}

*Values in parentheses are arcsine transformed values

\section{Treatment details}

S- Sterilized seed; US- Unsterilized seed

$\mathrm{T}_{0}$ - Nonprimed seeds

$\mathrm{T}_{1}$ - Hydropriming for 9 hours

$\mathrm{T}_{2}$-Biopriming with Bacillus subtilis 1at 6\% concentration for 9 hours

$\mathrm{T}_{3}$ - Biopriming with Methylobacterium extorquens $A M 1$ at $4 \%$ concentration for 9 hours

$\mathrm{T}_{4}$ - Biopriming with Pseudomonas fluorescens Pf 1 at $8 \%$ concentration for 9 hours 


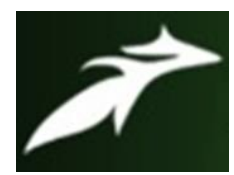

MOHAN RAJ $\mathrm{C}$ et al, International Journal of Advances in Agricultural Science and Technology, Vol.8 Issue.2, February-2021, pg. 55-61

ISSN: 2348-1358

Impact Factor: 6.057

NAAS Rating: 3.77

Fig. 2. Effect of seed biopriming on pathogen infection on the seeds of tomato $\mathrm{cv}$.

PKM 1 (Agar plate method).

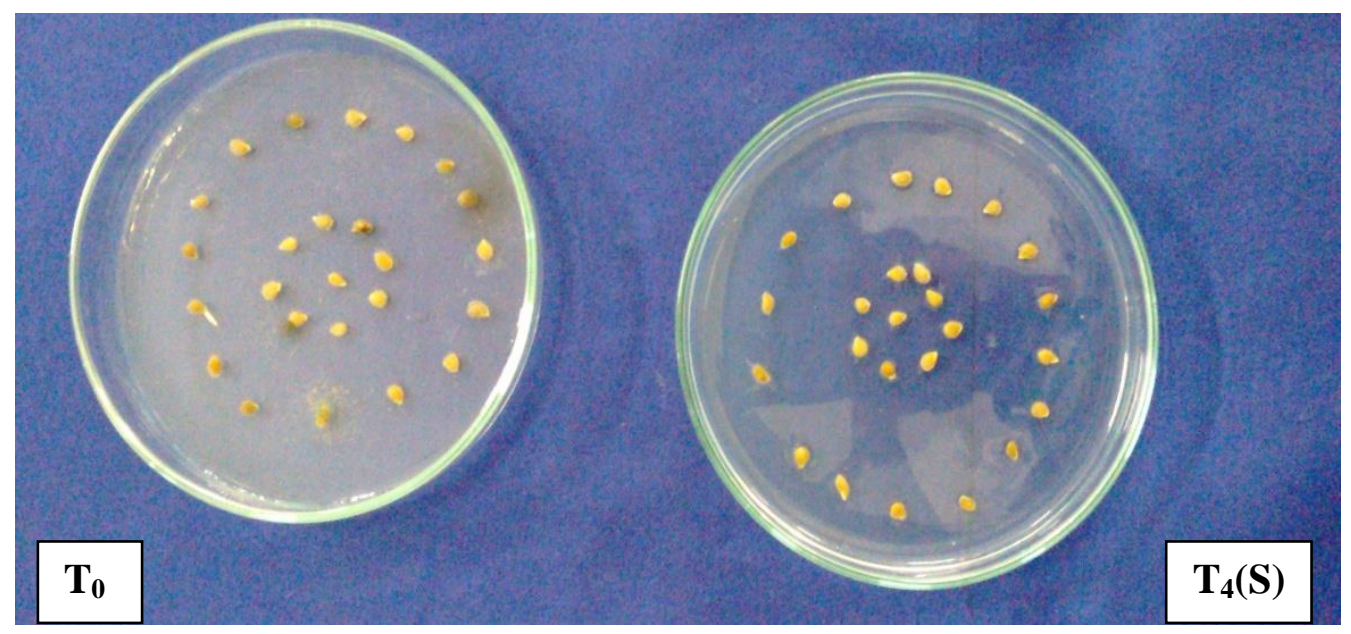

S- Sterilized seed; US- Unsterilized seed

$T_{0}$ - Nonprimed control

$\mathrm{T}_{4}$ (S) - Biopriming with Pseudomonas fluorescens Pf 1 at $8 \%$ concentration for 9 hours

Fig 3. Pathogens identified on the seeds of tomato cv. PKM 1 using light

microscope
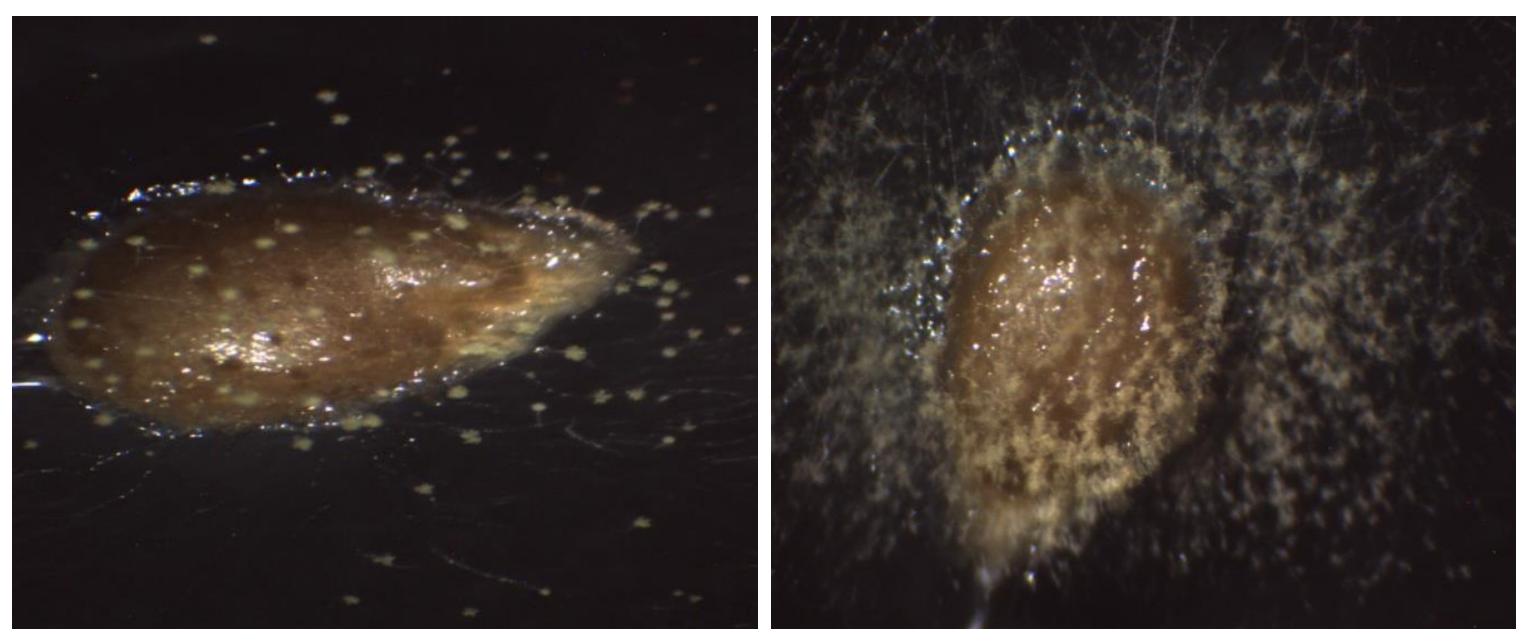

Aspergillus flavus

Fusarium .sp

The reason for the suppression of pathogen might be due to the reason that Pseudomonas are potential biocontrol agents, that showing competitive interactions with 


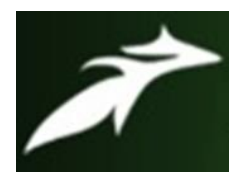

MOHAN RAJ C et al, International Journal of Advances in Agricultural Science and Technology, Vol.8 Issue.2, February-2021, pg. 55-61

ISSN: 2348-1358

Impact Factor: 6.057

NAAS Rating: 3.77

other micro organisms including fungi, bacteria, protozoa and nematodes by producing lipopeptide bio-surfactants as proposed by De Bruijn et al. (2007) and Raaijmakers et al.(2010).

\section{CONCLUSION}

This study concludes that the sterilized tomato seeds bioprimed with Pseudomonas fluorescens $\mathrm{Pf}$ 1at $8 \%$ concentration for 9 hours expressed least pathogen infection compared to the nonprimed seeds.

\section{LITERATURE CITED}

1. ISTA. 2010. International Rules of Seed Testing. Seed Sci. \& Technol., 27: 27-32.

2. Panse, V. G. and P. V. Sukatme. 1985. Statistical methods for agricultural workers. ICAR publication, New Delhi: 359.

3. Olouch, M. O. and G. E. Welbaum. 1996. Effect of post harvest washing and poststorage priming on viability and vigor of 6 year old muskmelon (Cucumis melo L.) seeds from eight stages of development. Seed Sci. and Technol., 24: 195-209.

4. Bradford, K. J. 1986. Manipulation of seeds water relations via osmotic priming to improve germination under stress conditions. Hort. Sci., 59(2): 672-676.

5. De Bruijn, I., M. J. D. de Kock, M. Yang, P. de Waard, T. A. van Beek and J. M. Raaijmakers. 2007. Genome-based discovery, structure prediction and functional analysis of cyclic lipopeptide antibiotics in Pseudomonas species. Mol. Microbiol., 63:417-428.

6. Raaijmakers, J. M., I. de Bruijn, O. Nybroe and M. Ongena. 2010. Natural functions of lipopeptides from Bacillus and Pseudomonas: More than surfactants and antibiotics. FEMS Microbiol. Review, 34:1037-1062. 